\title{
Should Cytochrome P450 Inducers be Used to Accelerate Clearance of Brodifacoum from Poisoned Patients?
}

\author{
Israel Rubinstein ${ }^{1,2} \cdot$ Richard van Breemen $^{3} \cdot$ Daniel G. Nosal ${ }^{3} \cdot$ Guy Weinberg ${ }^{1,2} \cdot$ Ronald C. Hershow $^{1}$. \\ Douglas L. Feinstein ${ }^{1,2}$ (1)
}

Published online: 28 January 2019

(c) The Author(s) 2019

\begin{abstract}
A recent multi-state outbreak of life-threatening bleeding following inhalation of synthetic cannabinoids has been attributed to contamination with the long-acting anticoagulant rodenticide (LAAR) brodifacoum, a second-generation, highly potent, long-acting derivative of the commonly used blood thinner warfarin. While long-term treatment with high-dose vitamin K1 restores coagulation, it does not affect brodifacoum metabolism or clearance, and, consequently, brodifacoum remains in the human body for several months, thereby predisposing to risk of bleeding recurrence and development of coagulationindependent injury in extrahepatic tissues and fetuses. This has prompted the evaluation of pharmacological measures that accelerate brodifacoum clearance from poisoned patients. Since the induction of certain cytochrome P450 (CYP) enzymes accelerates warfarin metabolism, using CYP inducers, such as phenobarbital, to accelerate brodifacoum clearance seems plausible. However, unlike warfarin, brodifacoum does not undergo significant metabolism in the liver, nor have the effects of phenobarbital on vitamin K1 metabolism been previously determined. In addition, the safety of phenobarbital in brodifacoumpoisoned patients has not been established. Therefore, we propose that CYP inducers should not be used to accelerate the clearance of brodifacoum from poisoned patients, but that alternative approaches such as reducing enterohepatic recirculation of brodifacoum, or using lipid emulsions to scavenge brodifacoum throughout the body, be considered.
\end{abstract}

\section{Key Points}

1. Increased cases of poisoning due to the long-acting anticoagulant rodenticide (LAAR) brodifacoum requires reconsideration of methods to enhance its clearance.

2. Unlike the parent compound warfarin, brodifacoum does not undergo significant metabolism and, as such, methods to induce cytochrome P450 enzymes that can accelerate warfarin breakdown may not be effective.

3. Methods to scavenge brodifacoum from tissue storage sites or reduce its enterohepatic recirculation should be considered.

Douglas L. Feinstein

dlfeins@uic.edu

1 University of Illinois, 835 South Wolcott Ave, MC513, E720, Chicago, IL 60612, USA

2 Jesse Brown VA Medical Center, Chicago, IL, USA

3 Linus Pauling Institute, Oregon State University, Corvallis, OR, USA

\section{Introduction}

Long-acting anticoagulant rodenticides (LAARs) are second- and third-generation derivatives of the widely used anticoagulant warfarin (coumadin), and were developed following the appearance of warfarin resistance in rodents [1]. The primary mechanism of action of LAARs is the same as for warfarin, namely binding to and inhibition of vitamin $\mathrm{K}$ epoxide reductase component 1 (VKORC1) whose activity is necessary to maintain vitamin $\mathrm{K} 1$ at sufficient levels to serve as a co-factor for $\gamma$-glutamyl carboxylase (gGC)-dependent activation of thrombin proteins [2]. One of the most potent LAARs is brodifacoum (BDF), which in contrast to warfarin, possesses a greater hydrophobic nature ( $\log P$ approximately 8.5$)$, longer biological half-life (estimated 20 days or longer in rodents), undergoes limited metabolism, and is subject to enterohepatic recirculation [3]. These properties result in extremely low median lethal dose $\left(\mathrm{LD}_{50}\right)$ values, typically between 0.2 and $0.8 \mathrm{mg} / \mathrm{kg}$ in rodents, and an acute lethal dose in humans of approximately $15 \mathrm{mg} / \mathrm{kg}$ (Table 1). LAARs are used worldwide to eradicate rodent infestations; however, unfortunately, their increased 
Table 1 Physical, chemical, and biological properties of brodifacoum and warfarin

\begin{tabular}{lll}
\hline & Brodifacoum & Warfarin \\
\hline Melting point $\left({ }^{\circ} \mathrm{C}\right)$ & $232[39]$ & $161[40]$ \\
$\mathrm{p}$ Ka & $4.5[39]$ & $5.08-5.19[41]$ \\
Molecular weight & $523 \mathrm{Da}$ & $308 \mathrm{Da}$ \\
$\log P\left(25^{\circ} \mathrm{C}\right)$ & $8.5[39]$ & $0.7-2.7[41]$ \\
Number of metabolites & $1[25,39]$ & $6[16,42]$ \\
Type & Glucuronide & Oxidation \\
Position & $4-\mathrm{OH}$ & $\mathrm{C}-6,7,8,10$, and 4 \\
Enzymes & $\mathrm{UGT}$ & $\mathrm{CYP} 3 \mathrm{~A} 4$ \\
& & $1 \mathrm{~A} 1,1 \mathrm{~A} 2,2 \mathrm{C} 8$, \\
& & $2 \mathrm{C} 9,2 \mathrm{C} 18,2 \mathrm{C} 19$ \\
Acute oral LD & & \\
Rat & & $3-300 \mathrm{mg} / \mathrm{kg}[44]$ \\
Mouse & $221 \pm 14 \mu \mathrm{g} / \mathrm{kg} \mathrm{[43]}$ & $10-300 \mathrm{mg} / \mathrm{kg}[44]$ \\
Rabbit & $300-700 \mu \mathrm{g} / \mathrm{kg}[44]$ & $800 \mathrm{mg} / \mathrm{kg}[44]$ \\
Human & $192 \pm 29 \mu \mathrm{g} / \mathrm{kg}[38]$ & $6-15 \mathrm{mg} / \mathrm{kg}[45]$ \\
Biological half-life & $15 \mathrm{mg} / \mathrm{kg}(\mathrm{estimated})$ & $15-58 \mathrm{~h} \mathrm{[48]}$ \\
\hline
\end{tabular}

$U G T$ uridine 5'-diphospho-glucuronosyltransferase, $C Y P$ cytochrome P450, $L D_{50}$ median lethal dose

use has led to increased incidence of accidental poisonings, primarily in children, and unintentional exposure following accidental leakage [4]. In the majority of these cases, a single administration of fresh frozen plasma or vitamin $\mathrm{K} 1$ can restore coagulation to normal levels within a relatively short period; however, following ingestion of larger amounts, as often occurs in suicide attempts, daily administration of vitamin $\mathrm{K} 1$ is required for months to over 1 year [5], the time needed for serum LAAR levels to diminish to levels considered non-toxic $(<10 \mathrm{ng} / \mathrm{ml})$ [6]. While effective, the long treatment duration together with the high cost of vitamin $\mathrm{K} 1$ can lead to poor patient adherence and could promote the use of alternative methods of detoxification that are not proven to offer any additional benefit.

\section{Should Cytochrome P450 Inducers be Used to Increase Long-Acting Anticoagulant Rodenticide Detoxification?}

A recent outbreak of life-threatening coagulopathy and bleeding in Illinois $[7,8]$ and other States was determined to be due to inhalation of synthetic cannibinoids (SCs). Several case reports have described the occurrence of intracranial bleeding following SC use. In one case, a 23-year-old male suffered intracerebral hemorrhage (ICH) that was speculated to be due to the induction of multiple intracranial arterial stenosis (MIAS) that deteriorated to ICH [9]. Other cases include a Japanese patient with intracranial bleeding who had a history of arteriovenous malformation [10], and three reports of patients with subarachnoid hemorrhage (SAH) $[11,12]$. However, peripheral bleeding was not reported in any of these cases and coagulation measurements were normal. Following high performance liquid chromatography-tandem mass spectrometry (HPLC/MS-MS) analysis, it was concluded that the inhaled SCs were contaminated with long-acting anticoagulants (LAARs), primarily brodifacoum and also the less potent related molecules difenacoum and bromadiolone. The source of the LAAR contamination, which is not a byproduct of the SC synthesis reactions, has not been disclosed by law enforcement authorities investigating the outbreak. Whether it was accidental due to erroneous addition of LAARs during the SC synthesis, or intentionally added to inflict serious injury or death, is not known; however, the in-hospital treatment and follow-up care has prompted reconsideration of treatment options for these patients.

It is well-established that resuscitation of patients presenting with acute brodifacoum poisoning consists of administration of appropriate blood products along with parenteral vitamin K1 [13]. In the maintenance phase that follows, off-label, high-dose (up to $100 \mathrm{mg}$ ) oral vitamin K1 is prescribed daily for extended periods of time (months), with frequent monitoring of various coagulation parameters, such as international normalized ratio (INR) [5, 14]. This long, multi-pill (up to 20 tablets daily) regimen is expensive (cost estimate for a month's supply in the US $=\$ 37,000$ ) and taxing for patients and may lead to non-adherence and recrudescence of severe coagulopathy and bleeding [15]. Hence, means to enhance clearance of brodifacoum from the human body to reduce daily dose and shorten the duration of vitamin K1 therapy during the maintenance phase may prove beneficial.

One strategy that has been considered to enhance brodifacoum metabolism and elimination from poisoned patients is simultaneous administration of an hepatic cytochrome $\mathrm{P} 450$ inducer, such as phenobarbital, together with oral vitamin K1. Phenobarbital induces hepatic CYP1A2, CYP2B6, CYP2C9, and CYP3A4/5, as well as several UDP-glucuronosyltransferases. R-warfarin is metabolized by CYP1A2 (forming 6- and 8-hydroxywarfarin) and by CYP3A4 (to form 10-hydroxywarfarin). S-warfarin is metabolized primarily by CYP2C9 to 7-hydroxywarfarin [16]. Studies showing that phenobarbital can reduce warfarin efficacy were reported as early as 50 years ago $[17,18]$. Since that time, numerous articles have demonstrated, both in adult [19] and pediatric [20] patients, that coadministration of phenobarbital significantly reduces warfarin efficacy, requiring higher doses to normalize INRs. Direct measurements have shown that warfarin clearance is increased up to $30 \%$ by phenobarbital [21], primarily due to the induction of CYP2C9 [22]. Based on these studies, it was subsequently 
reported that pretreatment with phenobarbital decreased the anticoagulant effects of brodifacoum in poisoned rats [3]; however, the effects of phenobarbital administration after exposure to brodifacoum, as is the case in poisoned patients, was not reported in that study, nor were observations validated in a second animal species.

Nonetheless, it is not clear that induction of P450 cytochromes or glucuronosyltransferases would influence brodifacoum metabolism or clearance. In contrast to warfarin, human brodifacoum metabolism by CYP enzymes or UDP-glucuronosyltransferases in hepatic microsomes or human hepatocytes is limited and its excretion is slow [23]. Ultra-high performance liquid chromatography (UHPLC)-tandem mass spectrometric studies have shown no evidence of phase I or phase I metabolism of brodifacoum in humans [24]. Multiple human poisoning case studies have reported detection, and sometimes measurement, of brodifacoum levels in blood, but none have reported detection of brodifacoum metabolites. In addition, no brodifacoum or brodifacoum metabolite has been reported in human urine. Instead, unmodified brodifacoum appears to be excreted from the liver into bile fluid and then into the gut. The sole exception to this understanding has been an environmental protection agency (EPA) contractor report using radiolabeled brodifacoum administered to rats fitted with bile duct catheters, suggesting that a brodifacoum glucuronide might be excreted in bile [25]. However, bile could only be obtained from two of three rats in that study, there was no spectroscopic confirmation of brodifacoum glucuronide, and a rat liver profusion study by the same investigators showed no evidence of brodifacoum metabolism. In lieu of an extensive metabolizer, the parent compound is primarily excreted from the liver into bile fluid and gut essentially unchanged. In the gut, brodifacoum undergoes extensive enterohepatic circulation that results in extremely slow fecal elimination from the human body, and is a major reason for its prolonged coagulopathy. In our studies, we were unable to detect any metabolism of brodifacoum, either in vivo or in vitro [26] and in unpublished findings, nor, to our knowledge, are there any published reports that identified or characterized brodifacoum metabolites. Moreover, whether high-dose oral vitamin $\mathrm{K} 1$ is metabolized by phenobarbital-inducible CYP oxidase enzymes in humans, thereby reducing its efficacy, has not been determined [27].

Although no controlled clinical trials have been conducted to test the safety and efficacy of phenobarbital in brodifacoum-poisoned patients, a review of several case reports of patients treated simultaneously with oral vitamin $\mathrm{K} 1$ and phenobarbital (up to $200 \mathrm{mg}$ daily) during the maintenance phase failed to show improved survival, consistent reduction in the daily dose of vitamin $\mathrm{K} 1$, and/or hasten recovery. For instance, Routh et al. [28] treated a brodifacoum-poisoned patient with phenobarbital $30 \mathrm{mg}$ twice daily for 2 months, with no discernible response. Similar observations were reported by Poovalingam et al. [29] and Altay et al. [30]. In contrast, Watts et al. reported a case of recurrent brodifacoum poisoning in a $71 / 2$-year-old girl who was resistant to high-dose (up to $100 \mathrm{mg}$ daily) oral vitamin K1 therapy [31]. However, patient adherence to this demanding therapeutic regimen (up to 20 tablets daily) was not reported. Nonetheless, the patient was eventually treated with oral phenobarbital $2 \mathrm{mg} / \mathrm{kg}$ daily without concomitant vitamin K1 administration, and coagulopathy resolved within 3 weeks. The authors suggested that phenobarbital accelerated the resolution of brodifacoum poisoning by promoting degradation and excretion of brodifacoum from the liver, although they did not determine brodifacoum metabolites, either in blood or feces. Given the lack of metabolism of brodifacoum in the liver, the mechanism(s) underlying the salutary effects of phenobarbital in this case remain uncertain.

Brodifacoum-poisoned patients considered for daily oral phenobarbital and high-dose vitamin K1 would be required to adhere to both medicines for an extended period, a task that may not be readily accomplished. The lack of adherence for multiple-tablet regimens has been well documented, as has the case for antiretroviral treatment, which also requires excellent adherence $[32,33]$. The fatal case reported by Kruse and Carlson [34] in which both medicines were prescribed but the poisoned patient failed to take them, clearly illustrates this point. In addition, Lipton and Klaas [35] described a brodifacoum-poisoned woman with a long history of mental illness who did not adhere to both oral vitamin $\mathrm{K} 1$ and phenobarbital therapy during the maintenance phase, resulting in repeated admissions to the hospital for serious bleeding episodes.

Importantly, potential adverse events associated with long-term phenobarbital therapy at anticonvulsant doses, such as sedation, should be considered in brodifacoumpoisoned patients. The mental status of these patients who may be prone to spontaneous intracranial hemorrhage and falls would then have to be closely monitored throughout the maintenance phase. To this end, Hui et al. [36] treated a 76-year-old, brodifacoum-poisoned patient with high-dose vitamin K1 and phenobarbital; however, phenobarbital provoked nocturnal confusion and was discontinued after 1 month.

\subsection{Alternatives to Cytochrome P450 Inducers}

In lieu of using CYP inducers as a means to increase brodifacoum metabolism, alternative approaches should be considered that could accelerate brodifacoum clearance or alter its pharmacokinetic properties, for example by increasing protein binding or modifying its tissue distribution. Infusion of US FDA-approved lipid emulsions, 
such as those typically used for parenteral nutrition, have been shown to accelerate clearance and prevent toxicity in animal models of bupivacaine overdose [37]. The infusion of lipid emulsion (ILE) has been clinically translated to treat overdose associated with a variety of compounds, including local anesthetics, antidepressants, and barbiturates. The mechanism of action includes scavenging toxins from target organs and redistributing them to the liver for degradation and elimination. The efficacy of this approach is correlated to the lipid solubility of the toxin, suggesting it may be effective against molecules such as brodifacoum with extremely high $\log P$ values. Studies to assess the efficacy of ILE in animal models of brodifacoum poisoning are ongoing, and initial findings indicate partial reductions in overall mortality (Feinstein et al., unpublished observations). While ILE could increase brodifacoum delivery to the liver, as well as its biliary excretion, efficacy may be limited by both enterohepatic recirculation of brodifacoum and its lack of metabolism. Treatment with compounds that reduce recirculation, such as bile sequestrants, could be considered for use alone or in conjunction with ILE, to lower total body brodifacoum burden by accelerating clearance from the gut. In support of this, we showed that administration of the bile sequestrant cholestyramine to brodifacoum-poisoned rabbits increased survival to almost $100 \%$ [38]. Approaches that utilize other scavengers to sequester circulating brodifacoum, or reduce its binding to serum albumin, allowing for increased redistribution to the liver, should be considered.

\section{Conclusions}

Given these data, we propose that in the absence of controlled clinical trials, the routine use of phenobarbital to induce CYP oxidase enzymes in the liver to accelerate clearance of brodifacoum from poisoned patients, thereby shortening the duration of vitamin K1 therapy during the maintenance period, is not warranted. Other methods, such as lipid emulsions to scavenge brodifacoum from tissues, or bile sequestrants to reduce enterohepatic recirculation should instead be pursued.

Acknowledgements This work, and the preparation of this article, were supported by National Institute of Neurological Disorders and Stroke (US) Grant number 1U01NS083457 (DLF).

\section{Compliance with Ethical Standards}

Conflict of interest Israel Rubinstein, Richard van Breemen, Daniel G. Nosal, Guy Weinberg, Ronald C. Hershow, and Douglas L. Feinstein declare that they have no conflicts of interest. Guy Weinberg is founder of Lipid Rescue, Inc., and Douglas Feinstein and Israel Rubinstein are co-founders of EnSol Therapeutics, LLC.

Open Access This article is distributed under the terms of the Creative Commons Attribution-NonCommercial 4.0 International License (http://creativecommons.org/licenses/by-nc/4.0/), which permits any noncommercial use, distribution, and reproduction in any medium, provided you give appropriate credit to the original author(s) and the source, provide a link to the Creative Commons license, and indicate if changes were made.

\section{References}

1. Hadler MR, Shadbolt RS. Novel 4-hydroxycoumarin anticoagulants active against resistant rats. Nature. 1975;253:275-7.

2. Oldenburg J, Bevans CG, Muller CR, Watzka M. Vitamin K epoxide reductase complex subunit 1 (VKORC1): the key protein of the vitamin K cycle. Antioxid Redox Signal. 2006;8:347-53.

3. Bachmann KA, Sullivan TJ. Dispositional and pharmacodynamic characteristics of brodifacoum in warfarin-sensitive rats. Pharmacology. 1983;27:281-8

4. Feinstein DL, Brodsky S, Weinberg G, van Breeman R, Rubinstein I. Brodifacoum poisoning: a clear and present danger to public health in the USA. Toxicol Lett. 2017;268:71-2.

5. Rubinstein I, Weinberg G, van Breemen R, Hershow RC, Feinstein DL. Treatment for long acting anticoagulant rodenticide poisoning-beyond INR monitoring? Toxicol Commun. 2018;2:59-61.

6. Bruno GR, Howland MA, McMeeking A, Hoffman RS. Longacting anticoagulant overdose: brodifacoum kinetics and optimal vitamin K dosing. Ann Emerg Med. 2000;36:262-7.

7. Moritz E, Austin C, Wahl M, DesLauriers C, Navon L, Walblay $K$. Notes from the field: outbreak of severe illness linked to the vitamin $\mathrm{K}$ antagonist brodifacoum and use of synthetic cannabinoids-Illinois, March-April 2018. MMWR Morb Mortal Wkly Rep. 2018;67:607-8.

8. Micula-Gondek W, Ruales V, Zorn C, Angelino A. Synthetic cannabinoid-associated coagulopathy: case report. Psychosomatics. 2018. https://doi.org/10.1016/j.psym.2018.05.010.

9. Aydin S, Yuksel O, Aydin AE, Kizilkilic O, Celik SE. Intracerebral hemorrhage with multiple intracranial arterial stenoses in a synthetic cannabinoid "Spice" user. Asian J Neurosurg. 2018;13:522-4.

10. Tanei T, Morita Y, Yashima A, Wakita H, Takebayashi S, Nakahara $\mathrm{N}$, et al. Severe rhabdomyolysis and intracranial hemorrhage associated with synthetic cannabinoid: a case report [in Japanese]. No shinkei geka (Neurol Surg). 2014;42:867-71.

11. Sherpa D, Paudel BM, Subedi BH, Chow RD. Synthetic cannabinoids: the multi-organ failure and metabolic derangements associated with getting high. J Community Hosp Intern Med Perspect. 2015;5:27540.

12. Kling L, Legrum W, Netter KJ. Induction of liver cytochrome $\mathrm{P}-450$ in mice by warfarin. Comparison of warfarin-, phenobarbitone-, and cobalt-induced hepatic microsomal protein patterns by PAGE after partial purification on octyl-sepharose CL-4B. Biochemical pharmacology. 1985;34:85-91.

13. Caravati EM, Erdman AR, Scharman EJ, Woolf AD, Chyka PA, Cobaugh DJ, et al. Long-acting anticoagulant rodenticide poisoning: an evidence-based consensus guideline for out-of-hospital management. Clin Toxicol (Phila). 2007;45:1-22.

14. King N, Tran MH. Long-acting anticoagulant rodenticide (Superwarfarin) poisoning: a review of its historical development, epidemiology, and clinical management. Transfus Med Rev. 2015;29:250-8. 
15. Card DJ, Francis S, Deuchande K, Harrington DJ. Superwarfarin poisoning and its management. BMJ Case Rep. 2014;2014: pii: bcr2014206360.

16. Kaminsky LS, Zhang ZY. Human P450 metabolism of warfarin. Pharmacol Ther. 1997;73:67-74.

17. MacDonald MG, Robinson DS. Clinical observations of possible barbiturate interference with anticoagulation. JAMA. 1968;204:97-100.

18. Udall JA. Clinical implications of warfarin interactions with five sedatives. Am J Cardiol. 1975;35:67-71.

19. Laine K, Forsstrom J, Gronroos P, Irjala K, Kailajarvi M, Scheinin $\mathrm{M}$. Frequency and clinical outcome of potentially harmful drug metabolic interactions in patients hospitalized on internal and pulmonary medicine wards: focus on warfarin and cisapride. Ther Drug Monit. 2000;22:503-9.

20. Streif W, Andrew M, Marzinotto V, Massicotte P, Chan AK, Julian JA, et al. Analysis of warfarin therapy in pediatric patients: a prospective cohort study of 319 patients. Blood. 1999;94:3007-14.

21. Mungall DR, Ludden TM, Marshall J, Hawkins DW, Talbert RL, Crawford MH. Population pharmacokinetics of racemic warfarin in adult patients. J Pharmacokinet Biopharm. 1985;13:213-27.

22. Halpert J, Jaw JY, Balfour C, Kaminsky LS. Selective inactivation by chlorofluoroacetamides of the major phenobarbital-inducible form(s) of rat liver cytochrome P-450. Drug Metab Dispos Biol Fate Chem. 1990;18:168-74.

23. Palmer RB, Alakija P, de Baca JE, Nolte KB. Fatal brodifacoum rodenticide poisoning: autopsy and toxicologic findings. J Forensic Sci. 1999;44:851-5.

24. Hauck Z. Tissue distribution, pharmacokinetics and metabolism of brodifacoum: a superwarfarin [Ph.D. dissertation]. Chicago: University of Illinois at Chicago; 2017.

25. USEPA Reregistration Eligibility Decision Document-Rodenticide Cluster. Washington, DC: USEPA 738-R-98-007; 1998. p. 36. http://www.epa.gov/pesticides/reregistration/status.htm. Accessed 19 Jan 2018.

26. Hauck ZZ, Feinstein DL, van Breemen RB. LC-MS-MS analysis of brodifacoum isomers in rat tissue. $\mathrm{J}$ Anal Toxicol. 2016;40:304-9.

27. Park BK, Wilson AC, Kaatz G, Ohnhaus EE. Enzyme induction by phenobarbitone and vitamin $\mathrm{K} 1$ disposition in man. Br J Clin Pharmacol. 1984;18:94-7.

28. Routh CR, Triplett DA, Murphy MJ, Felice LJ, Sadowski JA, Bovill EG. Superwarfarin ingestion and detection. Am J Hematol. 1991;36:50-4.

29. Poovalingam V, Kenoyer DG, Mahomed R, Rapiti N, Bassa F, Govender P. Superwarfarin poisoning: a report of 4 cases. S Afr Med J. 2002;92:874-6.

30. Altay S, Cakmak HA, Boz GC, Koca S, Velibey Y. Prolonged coagulopathy related to coumarin rodenticide in a young patient: superwarfarin poisoning. Cardiovasc J Afr. 2012;23:e9-11.

31. Watts RG, Castleberry RP, Sadowski JA. Accidental poisoning with a superwarfarin compound (brodifacoum) in a child. Pediatrics. 1990;86:883-7.
32. Nachega JB, Parienti JJ, Uthman OA, Gross R, Dowdy DW, Sax $\mathrm{PE}$, et al. Lower pill burden and once-daily antiretroviral treatment regimens for HIV infection: a meta-analysis of randomized controlled trials. Clin Infect Dis. 2014;58:1297-307.

33. Sutton SS, Hardin JW, Bramley TJ, D'Souza AO, Bennett CL. Single- versus multiple-tablet HIV regimens: adherence and hospitalization risks. Am J Manag Care. 2016;22:242-8.

34. Kruse JA, Carlson RW. Fatal rodenticide poisoning with brodifacoum. Ann Emerg Med. 1992;21:331-6.

35. Lipton RA, Klass EM. Human ingestion of a 'superwarfarin' rodenticide resulting in a prolonged anticoagulant effect. JAMA. 1984;252:3004-5.

36. Hui CH, Lie A, Lam CK, Bourke C. 'Superwarfarin' poisoning leading to prolonged coagulopathy. Forensic Sci Int. 1996;78:13-8

37. Fettiplace MR, Weinberg G. Past, present, and future of lipid resuscitation therapy. JPEN J Parenter Enteral Nutr. 2015;39:72s-83s.

38. Lindeblad M, Lyubimov A, van Breemen R, Gierszal K, Weinberg G, Rubinstein I, et al. The bile sequestrant cholestyramine increases survival in a rabbit model of brodifacoum poisoning. Toxicol Sci. 2018;165:389-95.

39. Pubchem Identifier CID 54680676. https://pubchem.ncbi.nlm.nih. gov/compound/54680676. Accessed 19 Jan 2018.

40. Pubchem Identifier CID 54678486. https://pubchem.ncbi.nlm.nih. gov/compound/54678486. Accessed 19 Jan 2018.

41. Pesticide Registration and Control Division, Department of Agriculture, Fisheries and Food. Backweston Laboratory Complex, Celbridge, Co. Kildare, Ireland; 2012. http://enfo.agt.bme.hu/ drupal/sites/default/files/clh_proposal_warfarin_cz016705-16_ en.pdf. Accessed 19 Jan 2018.

42. Horak K, Fisher P, Hopkins B. Pharmacokinetics of anticoagulant rodenticides in target and non-target organisms. Anticoagulant Rodenticides and Wildlife. Emerg Top Ecotoxicol. 2018;5:87-108.

43. Kalinin S, Marangoni N, Kowal K, Dey A, Lis K, Brodsky S, et al. The long-lasting rodenticide brodifacoum induces neuropathology in adult male rats. Toxicol Sci. 2017;159:224-37.

44. Extension Toxicology Network. http://pmep.cce.cornell.edu/profi les/extoxnet/pyrethrins-ziram/warfarin-ext.html. Accessed 19 Jan 2018.

45. Ellenhorn MJ, Barcelous DG. Medical toxicology: diagnosis and treatment of human poisoning. New York: Elsevier; 1988. p. 210-21.

46. Olmos V, Lopez CM. Brodifacoum poisoning with toxicokinetic data. Clin Toxicol (Philadelphia). 2007;45:487-9.

47. Pavlu J, Harrington DJ, Voong K, Savidge GF, Jan-Mohamed R, Kaczmarski R. Superwarfarin poisoning. Lancet. 2005;365:628.

48. O'Reilly RA, Aggeler PM, Leong LS. Studies on the coumarin anticoagulant drugs: the pharmacodynamics of warfarin in man. J Clin Investig. 1963;42:1542-51. 